\title{
The mental map as an instrument to define indicators in complex systems: an application on the environmental knowledge of local horticultural farmers
}

\author{
O mapa mental como instrumento para definir indicadores em sistemas \\ complexos: sua aplicação no conhecimento ambiental local de horticultores
}

\author{
María Luz Blandi ${ }^{1}$ (D), Natalia Agustina Gargoloff ${ }^{1}$ (i), María José lermanó ${ }^{1}$ (i), \\ María Fernanda Paleologos ${ }^{1,2}$ (1), Santiago Javier Sarandón ${ }^{1,3}$ [i]

\begin{abstract}
${ }^{1}$ Laboratorio de Investigación y Reflexión en Agroecología (LIRA)-Facultad de Ciencias Agrarias y Forestales (FCAyF), Universidad Nacional de La Plata (UNLP), La Plata, Argentina. E-mail: marilublandi@hotmail.com; agustinagargoloff@gmail.com; mariajoseiermano@gmail.com; ferpaleologos@gmail.com; sjsarandon@gmail.com ${ }^{2}$ Consejo Nacional de Investigaciones Científicas y Técnicas (CONICET), La Plata, Argentina. E-mail ferpaleologos@gmail.com ${ }^{3}$ Comisión de Investigaciones Científicas de la Provincia de Buenos Aires (CIC), La Plata, Argentina. E-mail: sjsarandon@gmail.com
\end{abstract}

\begin{abstract}
How to cite: Blandi, M. L., Gargoloff, N. A., lermanó, M. J., Paleologos, M. F., \& Sarandón, S. J. (2022). The mental map as an instrument to define indicators in complex systems: an application on the environmental knowledge of local horticultural farmers. Revista de Economia e Sociologia Rural, 60(1), e233521. https://doi.org/10.1590/1806-9479.2021.233521
\end{abstract}

\begin{abstract}
The reductionist and disciplinary paradigm of the Green Revolution coexists with the emerging paradigm of complexity, which values the holistic and the interdisciplinary. Agroecology promotes the need to understand the multiple biophysical relationships that exist in agroecosystems, and this calls for the development of new methodological tools. Sustainability indicators are an example of this. However, their implementation is not simple, as this requires an instrument to simplify the construction of such indicators. The objective of this work is to use the "mental map" as a guide for the development and application of indicators. The graph follows the conceptual path that facilitates the understanding of the variable and its breakdown into smaller and measurable units of analysis, i.e. the indicators. The created mental map has two stages: the development of indicators and their application. Its utility is presented in a case study that addresses local environmental knowledge (LEK). The results of this work show that complexity can be translated into quantifiable, measurable, and comparable variables, without this representing the loss of its characteristics. In addition, it proves that the created tool facilitates the evaluation and understanding of the functioning of agroecosystems, which contributes to decisionmaking.
\end{abstract}

Keywords: agroecology, indicators, sustainability, conceptual map, agrobiodiversity, complexity.

Resumo: O paradigma reducionista e disciplinar da Revolução Verde coexiste com o paradigma emergente da complexidade, o qual valoriza o holístico e o interdisciplinar. A Agroecologia promove a necessidade de compreender as múltiplas relações biofísicas existentes nos agroecossistemas, e isso exige o desenvolvimento de novas ferramentas metodológicas. Os indicadores de sustentabilidade são um exemplo disso. No entanto, sua implementação não é simples, pois requer um instrumento que simplifique a construção de tais indicadores. O objetivo deste trabalho é utilizar o "mapa mental" como guia para o desenvolvimento e a aplicação de indicadores. O gráfico segue o caminho conceitual que facilita o entendimento da variável e sua desagregação em unidades de análise menores e mensuráveis, ou seja, os indicadores. O mapa mental criado possui duas etapas: o desenvolvimento dos indicadores e sua aplicação. Sua utilidade é apresentada em um estudo de caso que aborda o conhecimento ambiental local (LEK). Os resultados deste trabalho mostram que a complexidade pode ser traduzida em variáveis quantificáveis, mensuráveis e comparáveis, sem que isso represente a perda de suas características. Além disso, comprova que a ferramenta criada facilita a avaliação e a compreensão do funcionamento dos agroecossistemas, o que contribui para a tomada de decisões. 
Palavras-chave: agroecologia, indicadores, sustentabilidade, mapa conceitual, agrobiodiversidade, complexidade.

\section{INTRODUCTION}

Although, in recent decades, industrial agriculture has increased the productivity and apparent profitability of agricultural systems, it has also caused serious ecological, productive, economic, and social problems that point to the crisis of the current model of agricultural production and cast doubt on its permanence in time (Altieri \& Nicholls, 2020; Andrade, 2011).

One of the reasons for this crisis is that, under the paradigm of the still predominant Green Revolution, the study of agricultural systems has been approached in a reductionist and disciplinary manner. From this paradigm of simplicity, cultural aspects are exclusively addressed by the social sciences, such as anthropology and sociology, while biological and technological aspects are exclusively studied by the biological sciences, such as agronomic sciences, ecology, and soil science, among others. However, agroecosystems are complex systems, where the biological and cultural components are closely related (United Nations Environment Programme, 2000; Toledo \& Barrera-Bassols, 2008, Teixeira \& Pires, 2017). Therefore, when a problem worsens, the effects spread throughout the system, influencing other problems. For example, the current pandemic caused by COVID-19 evidenced that given the systemic nature of our world, the human, social and economic consequences in connection, for instance, with animal and ecological health are closely linked (Altieri \& Nicholls, 2020). Therefore, a shift from simplistic, reductionist, and mechanistic thinking to one of complexity is required to face the environmental challenge (Altieri \& Nicholls, 2020; Leff, 2019).

As Kuhn (2011) points out, science works among paradigms. When science, based on the dominant paradigm, manages to give suitable answers to different problems in society, this is considered a period of normal science and therefore it is not questioned. When, on the contrary, scientific communities fail to solve the problems by applying the dominant paradigm, their methods and theories begin to be questioned and a paradigm break is generated. For example, science has not been able to accurately determine the impact of pesticide application on human health. From this crisis, the need to find a new paradigm capable of providing suitable answers originates, which gives rise to a period of post-normal science (Ravetz \& Funtowicz, 2015). Such is the current state of affairs. The dominant reductionist paradigm coexists with an emerging paradigm that values the systemic and the holistic, where concern for future generations, complexity (Morin, 2000), and uncertainty are the distinguishing features (Ravetz \& Funtowicz, 2015). Thus, this new approach can provide better responses, for example, to pollution caused by the use of pesticides.

The incorporation of this new paradigm into science, in general, and into agricultural sciences, in particular, represents both a necessity and an enormous challenge. In this context, Agroecology emerges as a new scientific approach, which proposes a new way of thinking and doing agriculture from a holistic and interdisciplinary framework that allows for a better understanding of the complexity of agroecosystems in an integrated way, thereby breaking with the isolation of disciplines (Anderson et al., 2019). It draws on scientific disciplines such as agronomy, ecology, sociology, ethnobotany, and others, as well as the knowledge and experiences of farmers to design, manage and evaluate sustainable agroecosystems. Thus, Agroecology raises the need to move forward in addressing the complexity of agroecosystems, where new questions, problems, and complex challenges have arisen (Morin, 2000; Leff, 2019) and for which the reductionist approach is inappropriate. To address such issues, new instruments, and methodological tools are required to be able to both maintain their inherent complexity and to analyze it, and to encourage decision-making. While important progress has been achieved, it is still an unsolved issue.

In this sense, a field where great progress has been observed is in the analysis of sustainability (Viglizzo et al., 2006; Jónsdóttir, 2011; Speelman et al., 2007; Sarandón \& Flores, 2009). This complex (multidimensional) concept could be addressed through the methodology of indicator development. There are, however, variations in the methodology 
across authors. On the one hand, Viglizzo et al. (2006) and Jónsdóttir (2011) propose rigid and/or universal indicators. In these cases, indicators cannot always be applied universally nor are they transferable, since each study site has specific characteristics. Indicators that may be adequate to assess sustainability in one place may not be suitable for evaluation in another. For its part, in the MESMIS methodology, the indicators are constructed for each particular situation based on certain desirable fixed and pre-established attributes of sustainability (Speelman et al., 2007). On the other hand, other authors, such as Sarandón \& Flores (2009), developed a methodology that guides the development of indicators for each study site, based on the definition of sustainability. A key aspect in connection with the use of indicators is the achievement of coherence between the concept to be measured and the chosen indicators (the measurement variables). To achieve this, these authors propose to clearly define the concept to be evaluated to then break it down from the general to the particular until we reach the variables that can be measurable, i.e. the indicators. It is not simply a matter of mentioning those aspects that are considered appropriate to evaluate and convert them into indicators. It is essential to follow a logical process, a mental journey, from the most complex to the simplest, while maintaining multidimensionality and coherence. This is not a simple task, as it is necessary to understand the concept to be evaluated, to objectify it, to translate it into reality, and to put it into practice, i.e. to make it "measurable" through quantifiable variables.

Even though the methodology of indicators has been used in many studies to address sustainability, the challenge is to be able to use it in the analysis of other concepts that may be even more complex, such as the evaluation of ecosystem services, local environmental knowledge, socio-ecological resilience and the potential for biotic regulation, among others.

Although the methodology proposed by Sarandón \& Flores (2009) to evaluate sustainability is a breakthrough in the sense that, with a series of steps, the logical process is guided to disaggregate the concept until the indicators are obtained, this process is complex in itself because it has a certain degree of abstraction, it requires practice and it is not always simple.

Therefore, there is a need for an alternative instrument that simplifies the process of indicator development which can be useful to evaluate complex aspects. In this sense, the visualization of this process through graphic instruments, such as the Mental Map, could be of great help. Following Villalustre Martínez \& Del Moral Pérez (2010), graphic organizers, such as conceptual or mental maps, allow for the structuring of information with the support of visual representations where important elements can be highlighted and the explanatory or hierarchical relationships of a given topic can be seen. Through a structure of thought, they propose to disaggregate complex concepts to make them verifiable and/or measurable, to then analyze them and integrate their complexity, as defined by Kaplan et al. $(2017$, p. 257) as "[...] a mental representation that an individual uses to acquire, maintain, and retrieve information about the relative locations and attributes of phenomena in their environment [...]". Authors like Sullivan-Wiley \& Teller (2020) use ecological mental maps to understand decisions connected with land use, while other authors use co-constructed mental models to understand the stakeholders' perspective on agroecology (Van Hulst et al., 2020).

The present work seeks to offer a didactic instrument: the "mental map" that can guide the construction and application of indicators to manage any complex aspects without having to break them down extensively, and which allows for the observation and comparison of critical points and potentialities, among others. In addition, we propose to demonstrate its usefulness by using a case study to approach a complex concept such as local environmental knowledge (LEK). It is understood that the development of this type of methodologies is a step forward towards both the construction of agroecological knowledge and the understanding and sustainable management of agricultural systems. 


\section{DEVELOPMENT}

\section{Theoretical and methodological guidelines}

To facilitate the process of development and application of indicators, certain steps that can be considered universal are proposed and which aid this process, and these are organized into a "Mental Map". It is named that way because it is a graphic organizer of knowledge; in this case, it represents the conceptual path that facilitates the organization and understanding of the complex concept and its disaggregation into smaller, measurable units of analysis, which are, ultimately, the variables or indicators to be evaluated. The graph contributes to the prioritization of concepts, from general to specific, giving a coherent structure to the information, and allowing a logical visual journey through the sequential relation of concepts. It also helps to visualize the information integrally, since all the steps and their interrelations can be observed simultaneously. In addition, to improve visualization, arrows and different size fonts are used.

The created mental map has two stages: a) the development of indicators and b) their application (Figure 1).

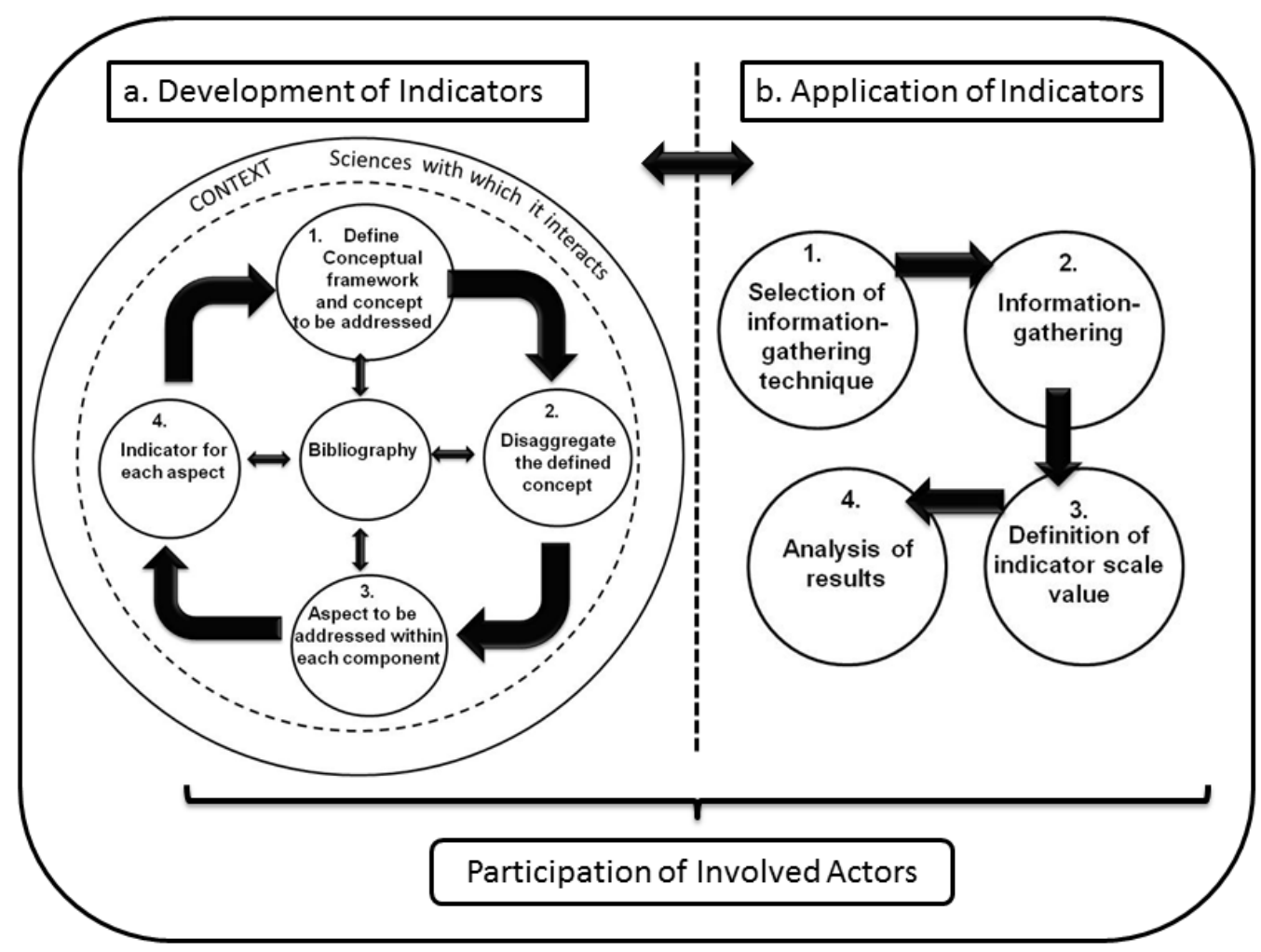

Figure 1. Mental map that represents the logical thinking towards the development of indicators (a) and the information-gathering process for their application (b).

The stage of indicator development (Figure 1a) comprises four initial steps: 1) the definition of the conceptual framework and the concept to be recognized, 2) the disaggregation of the defined concept into components, 3) the specification of the aspects to be addressed within each component and 4) the creation of the indicators. These steps are in constant interaction with bibliographic collection and analysis, as the indicators are constructed for each particular situation. 
The stage of indicator application (Figure $1 b$ ) is based on four other steps: 1 ) the selection of the information-gathering technique, 2) information-gathering, 3) the allocation of the scale value for the indicator and 4) the analysis of results. The stage of indicator development and the stage of indicator application are dependent and feed one another since the type of survey depends on the indicators, and the indicators, in turn, are constructed based on the surveying or sampling possibilities.

The actors involved in the process of construction and application of indicators are different depending on the type of study (farmers, researchers, politicians, consumers, extension workers, etc.) and the time of participation (throughout the process or in specific steps). In the case of agricultural studies, the participation of farmers is particularly important (Marandure et al., 2017; Jónsson et al., 2016; Teixeira \& Pires, 2017) since they are subjects of the research process and have an intimate relationship with the agroecosystem (Toledo, 2005). In the same way, Carlos et al. (2019) point out that to have successful regional public policies in the face of climate change, the perception, knowledge, and socioeconomic conditions of the individuals involved must be considered. According to Guzmán Casado et al. (2000), the participation of farmers in research can occur in different ways, depending on the adopted theoretical framework. In descriptive research, whose objective is to obtain empirical and quantitative data, the participation of farmers occurs only at the information-gathering stage (Silva-Laya et al., 2016). In comprehensive research, where qualitative information is generated and farmers can express their views on the problem that is being analyzed, farmers' participation can occur at the stage of indicator development (Marandure et al., 2017), for example, through participatory workshops. The researcher can make progress in connection with the most theoretical aspects of the first steps by generating a conceptual basis to be discussed in the workshop. Also, without conducting a workshop, the researcher can consider the opinion of the farmers in the interviews and modify the indicators so that they express the vision of the interviewees. In critical research, which aims to transform, farmers are the protagonists of the entire process, participating actively in each of the stages of development and application of indicators (Chango Amaguaña, 2014).

The steps for the construction and application of the indicators are described below.

\section{1.a Development of indicators}

\section{1.a. 1 Concept definition}

It is the necessary starting point to achieve coherence between the complex concept and its evaluation. It should start from a clear and extended definition of the meaning of the concept to be addressed to then be divided into the main components that structure this definition. For this, first of all, the adopted conceptual framework must be made explicit, along with the hypotheses and objectives of the analysis.

To achieve a robust and precise definition of what is to be evaluated or measured, the appropriate scientific support from the literature must be in place, and to do so, it is necessary to consider the related sciences and the existing theories concerning the concept that will be addressed to guide this search. Likewise, local knowledge needs to be contemplated through key informants, i.e. subjects that are well-informed, reflective, and willing to talk extensively with the researcher (Martín-Crespo Blanco \& Salamanca Castro, 2007).

The definitions that are more closely aligned with the selected conceptual framework should be chosen. In addition, these will depend on the situation to be analyzed, the context in which the study is inserted, and the level of evaluation. With these elements in mind, the concept that is to be analyzed can then be defined. For example, Sarandón et al. (2006), with a focus on sciences such as agronomy, ecology, economics, and sociology, defined as sustainable agriculture that which "allows to maintain over time a flow of goods and services that meet the socioeconomic and cultural needs of the population, within the biophysical limits that establish the correct functioning of the natural systems (agroecosystems) that support it". 


\section{1.a.2. Disaggregation of the defined concept into components}

This is the most critical step of the Mental Map. Here, the goal is to identify the main components that structure the definition, to disaggregate it into smaller parts, since the concept itself is only a definition that represents a block, and, therefore, cannot be used for decision-making. Therefore, the concept must be transformed into variables that can be measured later on.

Depending on the chosen definition, the concept is broken down into its components, which become "requirements" that can be fulfilled to a greater or lesser extent. The number of these components will depend on the adopted concept. For example, in the case of the sustainable use of water, Deluchi, Flores \& Sarandón (2015) disaggregated the concept into 2 dimensions to be evaluated: maintenance of the quantity and quality of the water resource. The clearer the adopted definition, the more coherent and simple it will be to break it down into smaller parts to be addressed at a later stage.

\section{1.a.3 Aspects to be addressed within each component or dimension}

Once the components or dimensions have been identified, the aspects to be developed within each one of these are selected, always bearing in mind the object of analysis and the conceptual framework. For this, we must take into account the characteristics that influence these aspects somehow. For example, in the case of agrobiodiversity, if temporal biodiversity is being evaluated, the aspects that most influence its composition are rotations, cultivation cycles, the frequency and intensity of disturbances caused by tillage, grazing, and harvesting, among others (lermanó et al., 2015). This type of reasoning enables the definition of the aspects that will become indicators.

\section{1.a. 4 Creation of indicators}

Indicators are qualitative or quantitative variables, made up of units, and which serve to identify a trend. They can be classified into state or pressure indicators. The first provides information on the current situation of the aspect to be evaluated. The second are those that indicate the effect that different factors exert on that aspect.

In order to facilitate the subsequent analysis, each indicator must comprise a scale, where each level represents different situations or states for such indicator. The highest points of the scale should represent the most desirable situations, while the lower levels represent the least desirable ones. In this way, all values, regardless of their original unit, are transformed to this scale, i.e. they are standardized, in order to allow for the comparison of indicators. This enables the integration of several indicators of different nature into others that may be more composite or reliable. Thus, complex aspects, such as the attitudes and visions of farmers, can be analyzed and compared (Blandi, 2016), which gives this tool a power that few instruments possess. The choice of content that will form each level will be based on the objectives, the available information, and the depth of the study, and it will depend on the information-gathering possibilities. That is why, for instance, indicators with scales of numerous levels, e.g. 5 options, or indicators with scales of fewer levels, e.g. 3 options, can be both used. The larger the scale, the more accurate, but the more difficult it will be to define each level.

\section{1.b Application of indicators}

\section{1.b.1 Selection of information-gathering techniques}

The instruments that will be used for data collection will be selected based on the objective of the research and the type of information that is to be gathered. One or more techniques may be used for the same study, depending on the indicators. If the information that is needed to complete the indicators is data at the macro or regional level, these can be obtained through bibliographic analysis and compilation (Abbona, 2017). If it is necessary to 
collect information on the biological components, generally at the agroecosystem level, sampling and its subsequent processing in the laboratory (for example, of cultivated species, spontaneous vegetation, arthropodofauna, etc.) will be required (Roboredo et al., 2016). In this step, the sampling technique must be defined, considering the type (for example floristic censuses, pitfall traps, etc.), quantity, distribution in the study universe, moment, etc., as well as laboratory processing techniques. Particular emphasis is given to surveys, questionnaires, and interviews since they are the most commonly used survey techniques when working with indicators. This is because they allow for the easy collection of a large amount of information. When the study and the constructed indicators contemplate issues related to knowledge, beliefs, and motivations, among others, it is convenient to interview the people where such knowledge is put into practice (Mello Amorozo \& Viertler, 2010). For example, if we are working with farmers, the place of the interview should be the same agroecosystem where production takes place.

\section{1.b.2 Survey of information}

It is the stage at which the bibliographic compilation, the interviews, or the samplings are carried out. In general, a request for consent is included for those involved, where the objective of the meeting is stated and explicit permission is requested to record, take pictures and samples, and publish the results of the research. This step can be accompanied by a sketch of the productive unit, field diary, notebook, direct observation, and free listings, among others (Albuquerque et al., 2010; Martin, 2000). In addition, it involves all the necessary materials to perform the samplings, if applicable to the study.

\section{1.b.3 Assigning the value of the scale of the indicator}

In this step, based on the collected information, the most relevant options for the scale are selected, i.e. the indicators are completed. To do so, the collected information must have been previously processed, either through laboratory work, transcription, systematization, and analysis of interviews, calculations in the cabinet, etc., which will allow us to obtain the final data to choose the appropriate value. For example, when the nutrient balance is used as an indicator, the information on inputs and outputs of nutrients is collected in the system, then the balance is calculated, and from the value obtained the most suitable option of the scale is chosen for the indicator. This procedure is repeated for each indicator, depending on the type of result required by the scale.

\section{1.b. 4 Analysis of results based on graphs or tables}

Finally, once the indicators are complete, the results can be shown in graphs or tables, depending on where the focus will be placed. One of the most commonly used graphs is the spider web graphic. This gives an integrated and holistic vision from which it is possible to reconstruct the concept simply. From the analysis of the graph, critical points and strengths are identified for each component, that is, the points closest to and furthest from the center, respectively. For example, if the analysis is performed at the farm level, this type of graph allows to easily visualize the differences across agroecosystems. Additionally, it is useful for comparing the results among groups of farmers or different production models (Roboredo et al., 2016; Marandure et al., 2017). To integrate the indicators into a single value, a weighted average can be used.

\section{CASE STUDY: DEVELOPMENT AND APPLICATION OF INDICATORS TO THE STUDY OF LOCAL ENVIRONMENTAL KNOWLEDGE OF AGROBIODIVERSITY IN HORTICULTURISTS FROM LA PLATA, ARGENTINA}

In this case, this tool was used to facilitate the process of analysis and to address the local environmental knowledge on agrobiodiversity possessed by family horticulturists in La Plata, Argentina (Figure 2) (Gargoloff, 2018). 


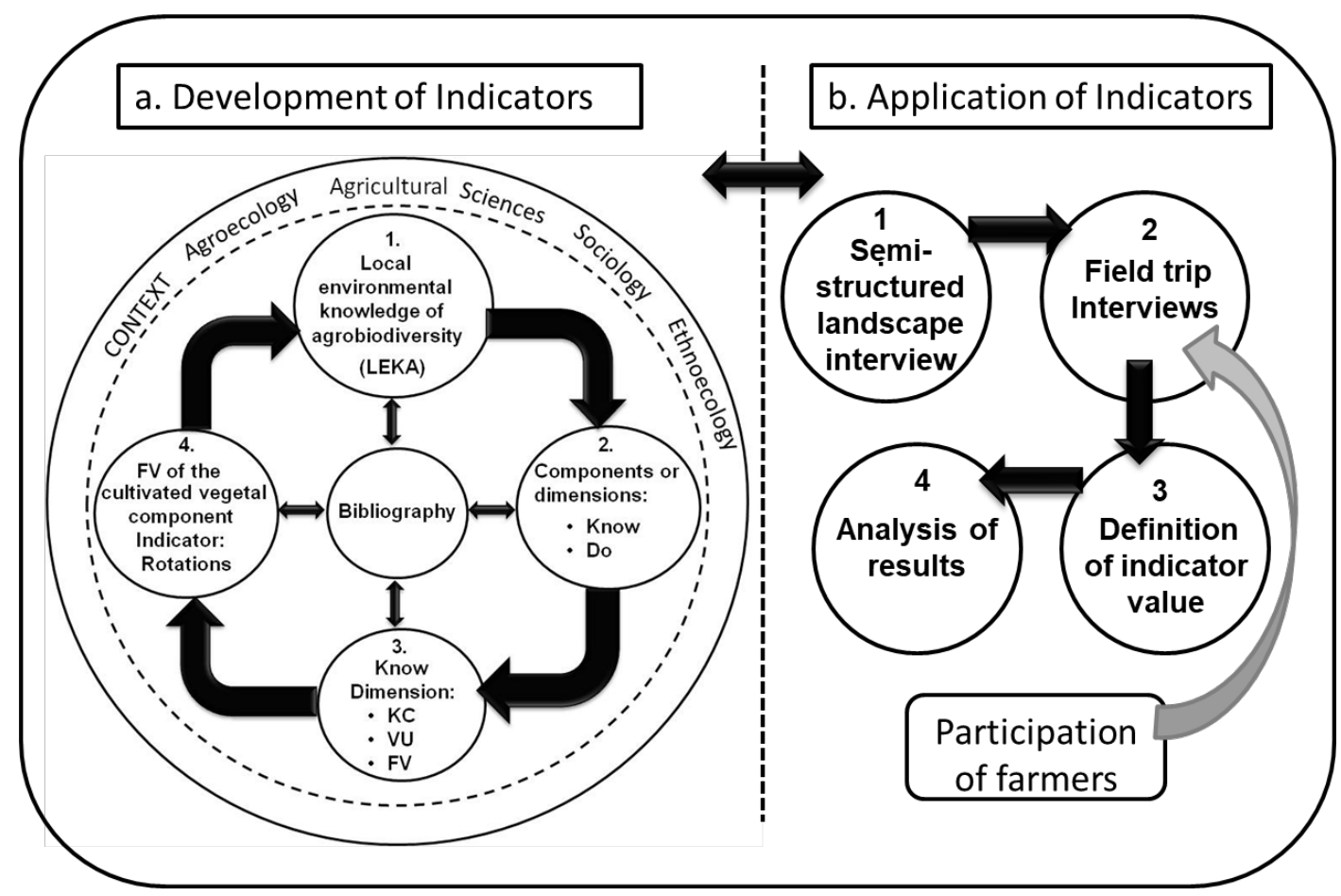

Figure 2. Mental Map: Construction process (a) and application of indicators (b) to the study of local environmental knowledge of agrobiodiversity in horticulturists in La Plata, Argentina. (KC): knowledge of the components, (VU): value of use, (FV): functional value.

\section{2.a Process for the construction of indicators}

\section{2.a. 1 Concept definition}

The conceptual framework and the concept to be addressed were defined using certain guiding questions such as: What is meant by local environmental knowledge? Why is local environmental knowledge important for sustainability?

From Agroecology, the knowledge and experience of traditional peasant and indigenous agriculture are recognized and valued as fundamental contributions for the development of sustainable and resilient agricultural systems. In this sense, it is understood that scientific, general, and theoretical knowledge is compatible and complementary to local knowledge, which is localized and often empirical, i.e. the "ecological rationality" that characterizes farmers (Toledo, 2005; Gliessman et al., 2007; Guzmán Casado \& Morales Hernández, 2012). The process of technical advice developed by Caatinga / PDHC and analyzed in Teixeira \& Pires (2017) shows the importance of valuing local knowledge for the success of their proposals. One of the reasons for this revaluation has been the knowledge and appreciation of agrobiodiversity by farmers, whose function is universal but its assembly and behavior are regional and localized (Gargoloff, 2018). Therefore, the achievement of sustainable and resilient management of agroecosystems requires a better understanding of agrobiodiversity in agroecosystems, and its relationship with the local knowledge of farmers. However, these aspects have not been addressed in systems with a recent history such as the agroecosystems of La Plata Horticultural Region.

Within this framework, the Local Environmental Knowledge of Agrobiodiversity (LEKA) is defined as "[...] the knowledge and appreciation that farmers have on the components, uses and functions of agrobiodiversity and the ecologically sound management of said component [...]" (Gargoloff, 2018, p. 57).

Documenting the LEKA and verifying whether there are differences across farmers is important because a more accurate and adequate knowledge of the potential of each 
agroecosystem can be achieved. This knowledge is vital for Agroecology and is an essential starting point for the design of management strategies for more sustainable agroecosystems.

\section{2.a.2 Disaggregation of the defined concept into components}

The definition of LEKA serves as a guide to disaggregate the concept into two components or dimensions: one linked to the knowledge and appreciation of farmers in terms of agrobiodiversity called the "Know" dimension (Table 1), and another that refers to the management, design or assembly of components that farmers perform on said natural resource, the "Do" dimension.

Table 1: Fields, categories, and indicators used in the analysis of the "Know" dimension: Indicators that include the knowledge and the assessment of the components, uses, and functions of agrobiodiversity by farmers. Source: taken from Gargoloff (2018).

\begin{tabular}{|c|c|c|}
\hline Context/Scope & Category & Indicators \\
\hline \multirow{3}{*}{$\begin{array}{l}\text { Knowledge of diversity } \\
\text { components }\end{array}$} & Cultivated vegetable & Crops \\
\hline & Spontaneous vegetable & $\begin{array}{l}\text { Recognition of spontaneous } \\
\text { vegetation }\end{array}$ \\
\hline & Animals (arthropods) & $\begin{array}{l}\text { Recognition of the animal } \\
\text { component }\end{array}$ \\
\hline $\begin{array}{l}\text { Value of direct use of the } \\
\text { vegetable component }\end{array}$ & $\begin{array}{l}\text { Vegetable (cultivated and } \\
\text { spontaneous) }\end{array}$ & Use of species \\
\hline \multirow[t]{7}{*}{$\begin{array}{l}\text { Functional value of diversity } \\
\text { components }\end{array}$} & Cultivated vegetable & $\begin{array}{l}\text { Origin of reproductive } \\
\text { material }\end{array}$ \\
\hline & & Number of cultivated species \\
\hline & & Spatial distribution of crops \\
\hline & & Crop association \\
\hline & & Rotations \\
\hline & Spontaneous vegetable & Ecological role \\
\hline & Animals (arthropods) & Ecological role \\
\hline
\end{tabular}

\section{2.a.3 Aspects to be addressed within each dimension}

In the next step, those aspects that are closely linked to each of the dimensions are defined and explained. Some of the questions used were: What aspects of knowledge and doing are considered for this study? What are the aspects that influence these dimensions? What characteristics define each dimension more specifically? How can the information provided by each of the dimensions be expanded?

According to lanni et al. (2015), local ecological knowledge is understood here as the ability of people to name the components of the agroecosystem (i.e. plants and animals), as well as knowledge of the functions and uses of each component. The three areas of analysis defined for the "Know" dimension derive from the foregoing: a) the recognition of the components of agrobiodiversity b) the direct use value that farmers ascribe to the spontaneous vegetable component and c) the value of functional use that farmers also recognize in the components. Each area was further specified and seven categories were included. In this way, along the path that began with the definition of the concept to be addressed and which continued with the definition of the particular aspects, these remained coherent with the conceptual framework.

The "Do" dimension was addressed using one area and three categories. The components of agrobiodiversity were established as the categories of analysis. These corresponded to the management of the following components: a) cultivated vegetables, b) spontaneous plants c) animals (arthropods). The aspects to be addressed within each category for the analysis of the management or assembly of the components of 
agrobiodiversity respond to the dimensions that according to Gliessman et al. (2007) allow for the analysis of the diversity of an agroecosystem in a disaggregated form considering the compositional, structural, and functional aspects of ecosystems including temporary changes. In this manner, it is possible to estimate the potential of ecological processes or functions such as, for example, biotic regulation which is favored as diversity becomes more complex in each of its dimensions.

\section{2.a.4 Creation of indicators}

At this stage, the questions that guided the definition and construction of the indicators were: What horticultural practices have an impact on the components of agrobiodiversity? What aspects of the design of the productive unit have an impact on the functions of agrobiodiversity? The indicators for each category, such as the number of cultivated species, the relationship between the cultivated area and the area of semi-natural environment, and the management strategy of the arthropod component were defined based on these questions.

Finally, a set of 19 indicators was developed, 11 of which corresponded to the "Know" dimension and 8 to the "Do" dimension. The indicators were developed and substantiated, based on the ease of obtaining the necessary data to complete the indicators. All indicators were standardized on a scale of 0 to 3; with 0 being the least desirable value and 3 being the optimal value. The 4-level scale was chosen as it was considered suitable for the objectives of the work and the available information. Then, the indicators of both dimensions were compared. In the "Know" dimension, all the indicators were given the same importance and in the "Do" dimension, each indicator had a different weight based on bibliographic support. As an example, we include the standardization of the rotation indicator for the "Know" dimension (Table 2). We sought to document whether gardeners considered the ecological benefits of increasing plant diversity over time through rotations.

Table 2: Scale for the Rotations Indicator of the "Know" dimension

$\begin{array}{cc}\text { Scale Value } & \text { Scale Definition } \\ 3 & \begin{array}{r}\text { Rotation with numerous species of different families is considered necessary based } \\ \text { on differential susceptibility to pests, diseases, and weeds and on nutritional } \\ \text { requirements }\end{array} \\ 2 & \text { Rotation with numerous species of different families is considered necessary based } \\ \text { on at least } 2 \text { susceptibilities and nutritional requirements }\end{array}$

\section{2.b Application of Indicators}

\section{2.b.1 Selection of the information-gathering technique}

The selected information-gathering technique was the semi-structured landscape interview type. The landscape interview included the drawing of a sketch of the productive unit. For some of the indicators, such as the use-value of spontaneous vegetation, the free listing technique was used (Albuquerque et al., 2010), as it is suitable for identifying cultural domain elements.

\section{2.b.2 Information-gathering}

Twelve farmers were interviewed between October 2010 and March 2013 in the horticultural region of La Plata. The fieldwork allowed us to find out the basis of this number with the saturation criterion of the cases (Martín-Crespo Blanco \& Salamanca Castro, 2007). 
Data were collected throughout this time and in a staggered manner as contact was established with each farmer. For this, informants were consulted to facilitate the selection of appropriate cases.

\section{2.b.3 Assignment of the value of the scale of the indicator}

After systematizing and analyzing the interviews, the most appropriate option on the scale was chosen for each indicator, which means that a value was assigned to each indicator. All the interviewed farmers were averaged to facilitate their interpretation and the results were expressed between 0 and 1.

\section{2.b.4 Analysis of the results according to graphs or tables}

Once the results were obtained, these were analyzed using a spider web graphic, where all the indicators could be observed simultaneously. Such a graph produced a holistic vision where complexity could be observed.

The results showed, for all farmers, that of all the values that they ascribe to biodiversity, there is less accumulation of knowledge in connection with less tangible aspects, such as functional value (FV) than with direct use value (UV) (Figure 3).

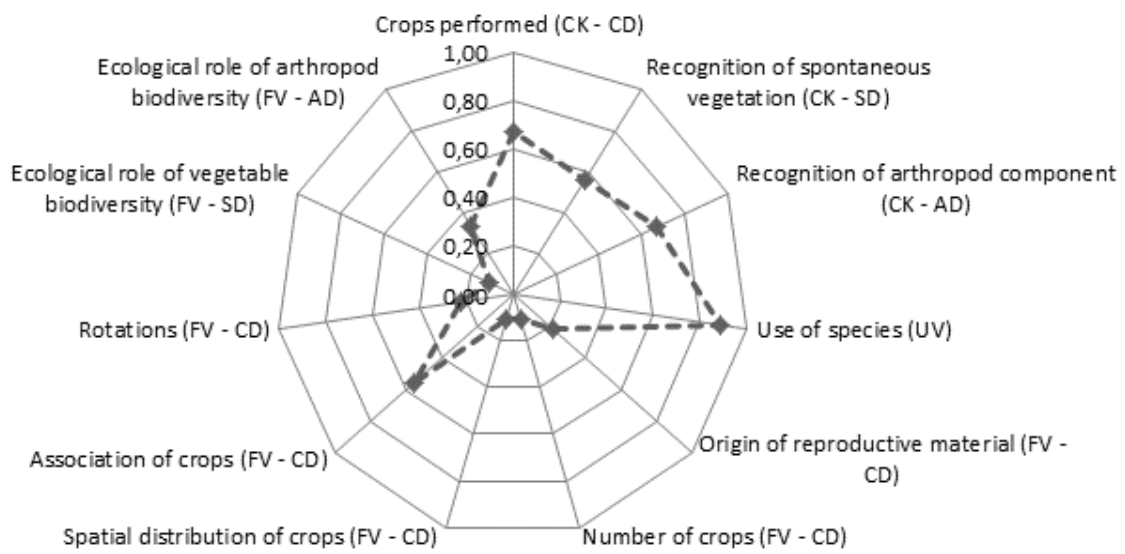

Figure 3. Results of indicators, expressed between 0 and 1, used in the analysis of the "Know" dimension. Differences in the knowledge and valuation of biodiversity for farmers with a tradition in horticulture. By the scope of analysis: knowledge of the components of biodiversity (CK), the use-value (UV), and the functional value of the said resource (FV). By category of analysis: cultivated diversity (CD), spontaneous diversity (SD), and diversity of arthropods (AD).

All the farmers recognized certain nutritional, biocidal, cosmetic, and/or medicinal properties of the plants (UV) and, to a lesser extent, the ecological benefits generated by having a high agrobiodiversity (FV) in the agroecosystem. Within what we call the FV, this graph allowed the easy identification of the critical aspects. In this sense, the ecological or functional role of plant diversity, arthropods, and certain practices such as rotations and simultaneous production of several species are undervalued.

However, this is not the case with other aspects, such as crop association or interplanting ${ }^{1}$, as there is implicit functional knowledge in said practice.

The following are examples that account for this. One of the farmers explains that, in the greenhouse, inter-planting green beans (Phaseolus vulgaris L.) and grilo (Brassica napus L.) helps as the pest has less protection "... Because, as it has more air before it was heavily wooded and there the bug is more protected, by having more air, it has less protection" [against possible

1 All expressions in italics are the farmers' own concepts. What appears in parentheses [] are the author's own agronomic interpretations. 
natural enemies or applications of agrochemicals]. In another case, sowing broad bean (Vicia faba L.) and green onion (Allium fistulosum L.) intercropped response to several criteria: to keep that furrow clean, otherwise, you would have to manage the weeds that grow in its place. Another reason the farmer mentions is that he does so to take advantage of the furrow; "...because the bean ... the plant grows much larger and always needs a furrow to make the harvest, so that there is room for the harvest, but until the bean comes out, I transplant green vegetables, something that comes out before they harvest, then you take advantage of the furrow...". Finally, he says that this association also serves as protection of the crop against pests. This knowledge allows adapting the intercropping practice to the specific needs and limitations of each case, which can range from ecological to economic and socio-cultural (Gargoloff, 2018). From an explanatory (science-specific) approach, associated crops will have a better behavior against spontaneous vegetation because, by using the soil intensively, this will be covered faster and, consequently, they will have less space and resources to grow. Another benefit attributed to intercropping is that of better biotic regulation that allows for the management of pests. Flores \& Sarandón (2014) point out that this benefit is linked to the changes that occur in the physical environment, by producing concealment, shading, and alteration of the color or at the level of biological interference due to the presence of adverse chemical stimuli, all of which make the finding of food by the pest difficult thus preventing an increase in its density. Therefore, it is essential to understand the ecological principles on which polycultures are based and that it is a site-specific practice (combinations of species cannot be linearly extrapolated from one site to another). In turn, it is equally important to place value on this functional knowledge to be able to successfully develop this practice. It is through observation, and through the active experimentation carried out by farmers through trial and error, that LEKA and practices are adapted.

In short, this analysis made it possible to bridge the gap between the conceptions of farmers and agronomists. The dialogue between Local Environmental Knowledge and science and its translation into management practices can help in the co-management of the sustainable use of agrobiodiversity. As indicated by Carlos et al. (2019), although their study focuses on the link between knowledge about climate change and the implementation of strategies to mitigate said event, it is of vital importance to incorporate local knowledge for decision-making and the successful implementation of these strategies. In the same way, the production systems in the northeastern semi-arid region of Brazil-based on agroecology studied in Teixeira \& Pires (2017) are an example of systems where the importance of the dialogue of knowledge is reaffirmed, in this case by technical advisers, as well as by exchanges of experiences among farmers, as an essential condition for the reproduction of the agroecological model.

Participation of involved actors: farmers

In this case study, farmers participated in the information-gathering stage by providing their knowledge and experience in connection with horticultural management. Although there was no explicit validation with farmers, the indicators were revised in the process of assigning the value of the scale and, in some cases, reformulated based on the interviews with farmers.

\section{DISCUSSION}

Agroecology understands that to achieve sustainable food systems, complex aspects that were not considered necessary or relevant until now must be urgently addressed (Morin, 2000; Leff, 2019) as these are essential to be able to evaluate progress in the right direction. For this, adequate, multidimensional instruments are required that allow for the analysis of several simultaneous dimensions while maintaining complexity, but which are clear enough to facilitate decision-making.

Furthermore, the local characteristics of agroecosystems suggest that evaluation systems must have a general methodological basis, but with a flexibility that allows them to adapt to each particular situation. One of the tools that allow to reliably evaluate complex aspects is the indicator development methodology. This methodology has been widely used 
for the evaluation of the environmental impact of agriculture or the evaluation of the sustainability of agroecosystems (Bockstaller et al., 2008; Sarandón \& Flores, 2009; Louwagie et al., 2012). However, such methodology requires a certain degree of abstraction, which is not easy to achieve. The process of indicator construction requires certain steps that can be slightly abstract and difficult. Therefore, tools are needed to facilitate their use and allow a more general use.

The construction of a mental map, such as the one proposed in this work, can help the construction and application of indicators by facilitating the approach to new complex aspects. One of its greatest assets is that it eases the organization and prioritization of information, which is of utmost importance when working with complex concepts (Villalustre Martínez \& Del Moral Pérez, 2010). In this sense, the graph represents a visual logical journey through the sequential relationship of concepts, from general to specific. It allows for the visualization of the interrelationships among concepts, thus contributing to the ability to observe the subject under study from an integrative perspective, which makes it useful to analyze complex concepts. This mental map can be applied to any multidimensional concept once the concept is clearly understood and disaggregated. Likewise, graphic structures such as shapes, colors, and short texts facilitate the organization and understanding of information (Muñoz González et al., 2015). On the other hand, in addition to detailing the construction of the indicators, it highlights the importance of the correct selection of the survey technique and its use, aspects that have remained undeveloped in the literature (Bockstaller et al., 2008), but which play an essential role for the successful outcome of the methodology.

The study demonstrated the usefulness of the mental map to guide, in a simple way, the construction of indicators to evaluate Local Environmental Knowledge on agrobiodiversity, which was disaggregated into minor concepts until simple measurable variables can be obtained, but without losing the holistic vision. The resulting indicators were applied in horticulturists of the La Plata horticultural belt and were pertinent and useful to detect the critical points and potentialities of the horticulturists concerning the addressed concept (Gargoloff, 2018). Therefore, the mental map is a simple instrument that allows to simplify a complex process, such as the construction of indicators, and to reach the desired result.

The methodological development of this work shows that complexity can be translated into quantifiable, measurable, and comparable variables, as was the case of the concept of sustainability (Sarandón \& Flores, 2009) in the beginning and, through this methodology, with other complex concepts such as the potential for biotic regulation (lermanó et al., 2015) and sustainable behavior (Blandi et al., 2013). In addition, it is shown that, with the tool developed in this work, decisions can be made, since it enables the evaluation and comparison of different systems or groups of farmers, as in the case study developed here.

This is aligned with Kaplan et al. (2017) who point out that map-type coding mechanisms can potentially facilitate decision-making.

Therefore, the mental map is an instrument that serves to solve problems, an aspect that is considered of vital importance (Kuhn, 2011).

The study of systems as complex as agricultural ones only fractionally addresses a part of reality and fails to understand such complexity. The methodological development of the present work proposes a breakthrough in connection with the approach, disaggregation, and analysis of complex aspects without oversimplifying reality, but at the same time, without getting lost in complexity. On the other hand, it can be complementary to other more complex studies. Likewise, to enrich the analysis of the information obtained with this quantitative methodology, it is convenient to use other qualitative methodologies such as the structural analysis of discourse (Demazière \& Dubar, 2010) or the ethnographic method (Martin, 2000), to deepen and understand the results obtained. Thus, both methodological approaches can be complementary, first, by simplifying the information, and then by understanding its complexity. Minayo \& Minayo-Gómez (2003) consider the complementary use of quantitative and qualitative methodologies desirable. While the first works with concrete data, the second is suitable to deepen the complexity of phenomena and facts. 


\section{CONCLUSION}

Agroecology understands that to achieve sustainable food systems, the complex aspects that until now were not presented as necessary or important must be addressed. Although the indicator methodology is a fundamental tool for this, its construction is complex. The mental map can make this task easier through its graphic structure with shapes and short texts, which facilitates the organization, prioritization, and understanding of information, which is of utmost importance when it comes to working with complex concepts. The graph represents a logical visual journey through the sequential relationship of concepts, from general to specific. Also, it allows the visualization of the interrelationships among concepts, thus contributing to the ability to observe the subject under study from an integrative perspective.

The case study demonstrated the usefulness of the mental map as a guide in the construction of indicators to evaluate the Local Environmental Knowledge of Agrobiodiversity, which was disaggregated into minor concepts until simple measurable and comparable variables are obtained, but without losing the holistic view. The resulting indicators were applied to horticultural farmers of the La Plata horticultural belt and were relevant and useful to detect the critical points and potentialities about the issue addressed.

Thus, the mental map is shown to be a tool that helps the methodology of indicators to achieve an approach from the starting point of complexity, to understand the functioning of agroecosystems, and to thus move forward towards sustainable agriculture.

\section{ACKNOWLEDGMENTS}

The authors would like to express their sincere gratitude to Consejo Nacional de Investigaciones Científicas y Técnicas (CONICET) and Facultad de Ciencias Agrarias y Forestales, Universidad Nacional de La Plata (FCAyF-UNLP). We would also like to thank the local farmers from the Region of La Plata who shared their time and knowledge.

\section{REFERENCES}

Abbona, E. A. (2017). Flujos de nutrientes en la agricultura y la alimentación para un ecosistema alimentario sostenible en la provincia de Buenos Aires (Tesis doctoral). Universidad Nacional de La Plata, La Plata.

Albuquerque, U. P., Farias de Paiva Lucena, R., \& Alencar, N. L. (2010). Métodos e técnicas para colecta de dados etnobiológicos. In: U.P. Albuquerque, R. Farias de Paiva Lucena \& L.V.F.C. Cunha (Eds.), Métodos e técnicas na pesquisa Etnobiológica e Etnoecológica (pp. 39- 64). Recife: ed. NUPEEA.

Altieri, M. A., \& Nicholls, C. I. (2020). La Agroecología en tiempos del COVID-19 (pp. 1-6). Berkeley: Centro Latinoamericano de Investigaciones Agroecológicas CELIA/ University of California.

Anderson, C. R., Bruil, J., Chappell, M. J., Kiss, C., \& Pimbert, M. P. (2019). From transition to domains of transformation: Getting to sustainable and just food systems through agroecology. Sustainability, 11(19), 5272. http://dx.doi.org/10.3390/su11195272

Andrade, F. (2011). La tecnología y la producción agrícola. El pasado y los actuales desafíos. Balcarce, Buenos Aires, Argentina: ed. INTA.

Blandi, M. L. (2016) Tecnología del invernáculo en el Cinturón Hortícola Platense: análisis de la sustentabilidad y los factores que condicionan su adopción por parte de los productores (Tesis doctoral). Universidad Nacional de La Plata, La Plata.

Blandi, M. L., Paleologos, M. F., Sarandón, S. J., \& Veiga, I. (2013). Identificación de impedimentos para avanzar hacia una "conducta sustentable" en pequeños horticultores de La Plata, Argentina. Cadernos de Agroecología, 8(2), 1. Retrieved in 2020, January 30, from http://revistas.abaagroecologia.org.br/index.php/cad/article/view/14982

Bockstaller, C. L., Guichard, L., Makowski, D., Aveline, A., Girardin, P., \& Plantureux, S. (2008). Agrienvironmental indicators to assess cropping and farming systems. A review. Agronomy for Sustainable Development, 28(1), 139-149. http://dx.doi.org/10.1051/agro:2007052 
Carlos, S. M., da Cunha, D. A., \& Pires, M. V. (2019). Conhecimento sobre mudanças climáticas implica em adaptação? Análise de agricultores do Nordeste brasileiro. Revista de Economia e Sociologia Rural, 57(3), 455-471. http://dx.doi.org/10.1590/1806-9479.2019.187600

Chango Amaguaña, E. F. (2014). Evaluación del avance agroecológico mediante indicadores de sustentabilidad en las fincas de la unión de organizaciones productoras agroecológicas y comercialización asociativa PACAT (Tesis de Maestría). Universidad Técnica de Ambato, Ecuador.

Deluchi, S. G., Flores, C. C., \& Sarandón, S. J. (2015). Análisis de la sustentabilidad del uso del recurso hídrico bajo tres estilos de producción hortícola en el Cinturón Hortícola Platense. Revista de la Facultad de Agronomía (La Plata), 114(2), 287-294. Retrieved in 2020, January 30, from http://revista.agro.unlp.edu.ar/index.php/revagro/article/view/342/286

Demazière, D., \& Dubar, C. (2010). Analyser les entretiens biographiques. L'exemple de récitsd'insertion. Questions Vives, 7(14), 177-179. http://dx.doi.org/10.4000/questionsvives.699

Flores, C. C., \& Sarandón, S. J. (2014). Manejo de la biodiversidad en agroecosistemas. In S.J. Sarandón \& C.C. Flores (Eds.), Agroecología: bases teóricas para el diseño y manejo de agroecosistemas sustentables (pp. 342-373). La Plata, Argentina: Editorial de la UNLP.

Gargoloff, N. A. (2018). Manejo, conocimiento y valoración de la agrobiodiversidad en fincas familiares de La Plata. Su relación con un manejo sustentable de los agroecosistemas (Tesis doctoral). Universidad Nacional de La Plata, La Plata.

Gliessman, S. R., Rosada-May, F. J., Guadarrama-Zugasti, C., Jedlicka, J., Cohn, A., Mendez, V. E., Cohen, R., Trujillo, L., Bacon, C., \& Jaffe, R. (2007). Agroecología: promoviendo una transición hacia la sostenibilidad. Ecosistemas (Madrid), 16(1), 13-23. Retrieved in 2020, January 30, from http://www.revistaecosistemas.net/articulo.asp?ld=459

Guzmán Casado, G., \& Morales Hernández, J. (2012). Agroecología y agricultura ecológica. Aportes y sinergias para incrementar la sustentabilidad agraria. Agroecología, 6, 55-62. Retrieved in 2020, January 30, from https://revistas.um.es/agroecologia/article/view/160671

Guzmán Casado, G., González de Molina, M., \& Sevilla Guzmán, E. (2000). Introducción a la agroecología como desarrollo rural sostenible. Madrid, España: ed. Mundi-Prensa.

Ianni, E., Geneletti, D., \& Ciolli, M. (2015). Revitalizing traditional ecological knowledge: a study in an alpine rural community. Environmental Management, 56(1), 144-156. http://dx.doi.org/10.1007/s00267-015-0479-z

lermanó, M. J., Sarandón, S. J., Tamagno, L. N., \& Maggio, A. D. (2015). Evaluación de la agrobiodiversidad funcional como indicador del "potencial de regulación biótica" en agroecosistemas del sudeste bonaerense. Revista de la Facultad de Agronomía (La Plata), 114(3), 1 14. Retrieved in 2020, January 30, from http://revista.agro.unlp.edu.ar/index.php/revagro/article/view/294/198

Jónsdóttir, E. M. (2011). Sustainability Assessment - Proposed Soil Indicators for Sustainability (Master's thesis). University of Iceland, Iceland.

Jónsson, J. O. G., Davidsdóttir, B., Jónsdottir, E. M., Kristindóttir, S. M., \& Ragnarsdóttir, K. V. (2016). Soil indicators for sustainable development: a transdisciplinary approach for indicator development using expert stakeholders. Agriculture, Ecosystems and Environment, 232, 179-189. http://dx.doi.org/10.1016/j.agee.2016.08.009.

Kaplan, R., Schuck, N. W., \& Doeller, C. F. (2017). The role of mental maps in decision-making. Trends in Neurosciences, 40(5), 256-259. http://dx.doi.org/10.1016/j.tins.2017.03.002

Kuhn, S. T. (2011). La estructura de las revoluciones científicas (4th ed.). México: Fondo de Cultura Económica.

Leff, E. (2019). Ecotechnological productivity: the emergence of a concept, its implications and applications for sustainable development. Bioeconomics Review, 2(1). Retrieved in 2020, January 30, from http://www.bioeconomicsreview.unipg.it/index.php/bioeconomics/article/view/6

Louwagie, G., Northey, G., Finn, J. A., \& Purvis, G. (2012). Development of indicators for assessment of the environmental impact of livestock farming in Ireland using the Agri-environmental Footprint Index. Ecological Indicators, 18, 149-162. http://dx.doi.org/10.1016/j.ecolind.2011.11.003.

Marandure, T., Mapiye, C., Makombe, G., \& Dzama, K. (2017). Indicator-based sustainability assessment of the smallholder beef cattle production system in South Africa. Agroecology and Sustainable Food Systems, 41(1), 3-29. http://dx.doi.org/10.1080/21683565.2016.1231152. 
Martin, G. J. (2000). Pueblos y plantas. Etnobotánica (Vol. 1). Reino Unido: Royal Botanic Gardens.

Martín-Crespo Blanco, M. C., \& Salamanca Castro, A. B. (2007). El muestreo en la investigación cualitativa. Nure Investigación, 27. Retrieved in 2020, January 30, from http://www.nureinvestigacion.es/OJS/index.php/nure/article/view/340

Mello Amorozo, M.C. \& Viertler, R.B. (2010). A abordagem qualitative na coleta e análise de dados em Etnobiológica e Etnoecológica. In: U.P. Albuquerque, R. Farias de Paiva Lucena \& L.V.F.C. Cunha (Eds.), Métodos e técnicas na pesquisa Etnobiológica e Etnoecológica (pp. 65-83). Recife: ed. NUPEEA.

Minayo, M. C. S., \& Minayo-Gómez, C. (2003). Difíceis e possíveis relações entre métodos quantitativos e qualitativos nos estudos de problemas de saúde. In P. Goldenberg, R. M. G. Marsiglia \& M. H. A. Gomes (Orgs.), O clássico e o novo (pp. 117-142). Río de Janeiro: FIOCRUZ.

Morin, E. (2000). Por una reforma del pensamiento. Revista Magistralis, 18, 61-71.

Muñoz González, J. M., Ariza Carrasco, C., \& Sampedro Requena, B. E. (2015). La aplicación de los mapas mentales en educación primaria. International Journal of Educational Research and Innovation, 4, 7089. Retrieved in 2020, January 30, from https://www.upo.es/revistas/index.php/IJERI/article/view/1459/1174

Ravetz, J., \& Funtowicz, S. (2015). Post-normal science. In S. Meisch, J. Lundershausen, L. Bossert \& M. Rockoff. Ethics of science in the research for sustainable development (pp. 99-112). Baden-Baden: Nomos Verlagsgesellschaft mbH \& Co. KG. http://dx.doi.org/10.5771/9783845258430-99.

Roboredo, D., Bergamasco, S. M. P. P., \& Bleich, M. E. (2016). Aggregate index of social-environmental sustainability to evaluate the social-environmental quality in a watershed in the Southern Amazon. Ecological Indicators, 63, 337-345. http://dx.doi.org/10.1016/j.ecolind.2015.11.042.

Sarandón, S. J., \& Flores, C. C. (2009). Evaluación de la sustentabilidad en agroecosistemas: una propuesta metodológica. Agroecología, 4, 19-28. Retrieved in 2020, January 30, from https://revistas.um.es/agroecologia/article/view/117131

Sarandón, S. J., Zuluaga, M. S., Cieza, R., Gómez, C., Janjetic, L., \& Negrete, E. (2006). Evaluación de la sustentabilidad de sistemas agrícolas de fincas en Misiones, Argentina, mediante el uso de indicadores. Agroecología, 1, 19-28. Retrieved in 2020, January 30, from https://revistas.um.es/agroecologia/article/view/14

Silva-Laya, S. J., Pérez-Martínez, S., \& Ríos-Osorio, L. A. (2016). Evaluación agroecológica de sistemas hortícolas de dos zonas del oriente antioqueño, Colombia. Revista Colombiana de Ciencias Hortícolas, 10(2), 355-366. http://dx.doi.org/10.17584/rcch.2016v10i2.5752.

Speelman, E. N., López-Ridaura, S., Colomer, N. A., Astier, M., \& Masera, O. R. (2007). Ten years of sustainability evaluation using the MESMIS framework: Lessons learned from its application in 28 Latin American case studies. International Journal of Sustainable Development \& World Ecology, 14(4), 345-361. http://dx.doi.org/10.1080/13504500709469735.

Sullivan-Wiley, K., \& Teller, A. (2020). The integrated socio-perceptual approach: Using ecological mental maps and future imaginaries to understand land use decisions. Global Environmental Change, 64, 102151.

Teixeira, C. T. M., \& Pires, M. L. L. S. (2017). Análise da relação entre produção agroecológica, resiliência e reprodução social da agricultura familiar no Sertão do Araripe. Revista de Economia e Sociologia Rural, 55(1), 47-64. http://dx.doi.org/10.1590/1234-56781806-94790550103

Toledo, V. M. (2005). La memoria tradicional: la importancia agroecológica de los saberes locales. LEISA Revista de Agroecología, 20(4), 16-19. Retrieved in 2020, January 30, from http://www.leisaal.org/web/index.php/volumen-20-numero-4/2073-la-memoria-tradicional-la-importanciaagroecologica-de-los-saberes-locales

Toledo, V. M., \& Barrera-Bassols, N. (2008). La memoria biocultural, la importancia ecológica de las sabidurías tradicionales. Icaria editorial. Junta de Andalucía. Consejería de Agricultura y Pesca.

United Nations Environment Programme. (2000, Mayo 15-26). The Biodiversity Agenda. Decisiones adoptadas por la conferencia de las partes en el convenio sobre la diversidad biológica en su quinta reunión. Nairobi. Retrieved in 2020, January 30, from https://www.cbd.int/doc/decisions/cop05/full/cop-05-dec-es.pdf

Van Hulst, F., Ellis, R., Prager, K., \& Msika, J. (2020). Using co-constructed mental models to understand stakeholder perspectives on agro-ecology. International Journal of Agricultural Sustainability, 18(2), 172-195. http://dx.doi.org/10.1080/14735903.2020.1743553 
Viglizzo, E. F., Frank, F., Bernardos, J., Buschiazzo, D. E., \& Cabo, S. (2006). A rapid method for assessing the environmental performance of commercial farms in the pampas of Argentina. Environmental Monitoring and Assessment, 117, 109-134. http://dx.doi.org/10.1007/s10661-006-7981-y.

Villalustre Martínez, L., \& Del Moral Pérez, M. E. (2010). Mapas conceptuales, mapas mentales y líneas temporales: objetos "de" aprendizaje y "para" el aprendizaje en Ruralnet. Revista Latinoamericana de Tecnología Educativa, 9(1), 15-27. Retrieved in 2020, January 30, from

https://www.researchgate.net/publication/46100195_Mapas_conceptuales_mapas_mentales_y_line as_temporales_objetos_'de'_aprendizaje_y_'para'_el_aprendizaje_en_Ruralnet

Received: January 30, 2020

Accepted: February 17, 202

JEL Classification: O13, Q01, Q56 